\title{
G-Centre Formation and Behaviour in a Silicon on Insulator Platform by Carbon Ion Implantation and Proton Irradiation
}

(Pembentukan Pusat-G dan Kelakuan dalam Silikon Pentas Penebat Implantasi Ion Karbon dan Sinaran Proton)

\author{
D.D. BERHANUDDIN*,N.E.A. RAZAK, M.A. LOURENÇO, B.Y. MAJLIS \& K.P. HOMEWOOD
}

\begin{abstract}
The interest in the G-centre is driven by reports that it can lase in silicon. To further this, the transfer of this technology from bulk silicon to a silicon-on-insulator (SOI) platform is an essential requirement to progress to lasing and optical amplification on silicon. We report on the efficient generation of the lasing $G$-centre in SOI substrates by proton irradiation of carbon ion implants. Following carbon implantation samples were annealed and then proton irradiated to form the $G$-centre and characterized by photoluminescence measurements. The temperature dependence of the emission and the behaviour of the $G$-centre with post proton annealing were investigated and results are compared with identical implants in control samples of bulk silicon. Overall, we find that the optically active G-centre can be up to $300 \%$ brighter and has better survivability over a wider process window in SOI than in bulk silicon.
\end{abstract}

Keywords: G-center; ion implantation; photoluminescence; point-defect; SOI

ABSTRAK

Pusat kecacatan titik yang menyinar, Pusat G mula mendapat perhatian apabila terdapat laporan mengatakan ia dapat menghasilkan laser di dalam silikon. Tambahan lagi, pemindahan teknologi daripada silikon pukal ke silikon-ataspenebat (SOI) adalah keperluan penting untuk kemajuan laser dan penguat optik daripada silikon. Kami melaporkan tentang janaan cahaya yang cekap, Pusat G di dalam substrat SOI dengan menggunakan teknik implantasi karbon ion dan penyinaran proton. Selepas penempelan karbon, sampel telah disepuh-lindap dan disinari dengan proton bertenaga tinggi untuk menghasilkan Pusat G yang kemudiannya akan dicirikan menggunakan kaedah pengukuran fotoluminesens. Sampel yang mempunyai keamatan cahaya paling tinggi daripada SOI dan silikon pukal dipilih untuk disepuh-lindap sekali lagi untuk mengkaji kesan pembentukannya, dan pemusnahan pusat kecacatan titik. Secara keseluruhan, kami merumuskan pusat kecacatan titik yang menyinar Pusat G dapat menyinar pada lebih 300\% dan mempunyai kemandirian yang lebih baik di dalam SOI berbanding silikon pukal.

Kata kunci: Fotoluminesen; kecacatan titik; penempelan ion: pusat G; SOI

\section{INTRODUCTION}

Silicon photonics combines waveguided optical devices and functionality with standard silicon microelectronics circuits integrated on a single chip on a standard siliconon-insulator (SOI) platform. The booming of the silicon photonics, stimulated by a series of recent breakthroughs is the main drive of the aforementioned research. Silicon photonics is an important, developing field that offers a route to fast computer chips and telecommunication by integration of optical components with electronics. There is also an urgent requirement to create a silicon-based optical emitter that is compatible with standard ULSI technology used in fabricating integrated circuits (Homewood et al. 2005). Despite silicon dominance in the electronics industry, it is still lacking key properties in optoelectronics. This is because of the indirect band gap, which limits the radiative recombination efficiency.

However, in the past decade, various approaches have been studied to try circumventing the band gap limitation, thus transforming silicon as an optically active material
(Yukhnevich 2007). Among the successful and promising methods of emitting light from silicon are point-defect centres (Bao et al. 2007; Berhanuddin et al. 2018, 2016; Murata et al. 2011; Rotem et al. 2007), Raman conversion (Boyraz \& Jalali 2004; Rong et al. 2005), strained silicon i.e. dislocation engineering(Homewood \& Lourenco 2005; Kittler et al. 2005; $\mathrm{Ng}$ et al. 2001), and nanocrystals with or without rare earth doping such as erbium (Er) (Bagiah et al. 2016; Jurbergs et al. 2006; Lourenco et al. 2016; Pavesi et al. 2000; Walters et al. 2005). The first silicon laser was reported in 2004 by using the Raman conversion technique, however, by its nature can only ever be optically pumped (Boyraz \& Jalali 2004). Among the successful and promising methods of obtaining light emission from silicon is the manipulation of point defect centres to produce emission at certain wavelengths as this technique is fully compatible with the current silicon CMOS technology (Berhanuddin et al. 2012a).

The G-centre as an emissive point defect gained lots of attention due to its sharp zero phonon luminescence peak 
at a wavelength of $1.28 \mu \mathrm{m}(0.97 \mathrm{eV})$ with the evidence of lasing occurred in the structure (Cloutier et al. 2005). The emission of the G-centre is attributed to the carbon substitutional-carbon interstitial $(\mathrm{Cs} \mathrm{C} i)$ complex, which interacts with silicon interstitials during the damage event. The G-centre emission at $1280 \mathrm{~nm}$ is in the spectral range that is vital in long-haul fiber-optic networks and is ideally suited to silicon intra-chip and inter-chip lowpower data interconnects. A new method fully compatible with complementary metal oxide semiconductor (CMOS) technology to produce the lasing G-centre has been reported (Beaufils et al. 2018; Berhanuddin et al. 2012b). The technique combines implantation of carbon, subsequent heat treatment followed by high energy proton implantation on bulk silicon substrates to form $\mathrm{C}_{s} \mathrm{C}_{i}$ complexes and $\mathrm{Si}$ interstitials. The luminescence intensity of the G-centre emission varies with the implant conditions such as the carbon and proton doses.

The next critical step is to transfer this new technology to the silicon-on-insulator (SOI) platform to provide the optical confinement as the result of a very large refractive index contrast between the $\mathrm{Si}$ and $\mathrm{SiO}_{2}$ for future amplifier and laser structures. Furthermore, SOI wafers are now the main material used in CMOS Silicon technology because of their attractive quality of improving the device performance for the same device dimensions as in bulk Si substrates. Therefore, the transfer of light technology from bulk to SOI platform is crucial for future integration of electronics and photonics industry.

In this paper, we report the implementation of the new CMOS compatible technique to generate the G-centre on an SOI platform. Photoluminescence measurement have been carried out after carbon implant and high energy proton irradiation at different temperatures to investigate the $G$ centre's peak and other related luminescence intensity in bulk silicon and SOI samples. Next, each sample from both bulk silicon and SOI wafers that have the highest G-centre peak's intensity were annealed to see the effect of annealing on the formation and annihilation of the optically active point-defect centres. The annealing effect is one of the main concern before proceeding to the next step of realizing the LED structure on the SOI platform. It is known that the G-centre can be destroyed by annealing at $\mathrm{T}>250^{\circ} \mathrm{C}$ (Davies 1989). However, the destruction of the G-centre in SOI samples has yet to be confirmed. The presence of the silicon/silicon dioxide interface potentially makes this transfer non trivial, so its successful demonstration is the key to further development towards devices.

\section{METHODS}

Samples were fabricated on (100) n-type silicon wafers and (100) p-type SOI wafers with resistivity of $\sim 10 \Omega \mathrm{cm}$ and $2000 \Omega \mathrm{cm}$, respectively. The SOI wafer had a $450 \mathrm{~nm}$ silicon overlayer and a $1 \mathrm{~mm}$ thick oxide. All samples had the same carbon implantation doses and energies: $4 \times 10^{13} \mathrm{C}$ $\mathrm{cm}^{-2}$ at $30 \mathrm{keV}$ followed by $1.1 \times 10^{13} \mathrm{C} \mathrm{cm}^{-2}$ at $10 \mathrm{keV}$. The dual carbon implantations were performed to construct a reasonably flat carbon profile providing better uniformity of the carbon concentration along the depth of samples. The carbon volume concentration across the middle of the implant after both implantations is $4 \times 10^{18} \mathrm{~cm}^{-3}$ calculated using SUSPRE (Webb 2001). After the $\mathrm{C}$ implantation, samples were annealed at $1000^{\circ} \mathrm{C}$ for $20 \mathrm{~s}$ in $\mathrm{N}_{2}$ ambient to repair the lattice damage and to introduce the carbon into the substitutional sites. Proton irradiation of the annealed samples were subsequently carried out at fluences of either $3 \times 10^{13} \mathrm{~cm}^{-2}$ or $1 \times 10^{14} \mathrm{~cm}^{-2}$ at $2 \mathrm{MeV}$.

Samples were mounted in a cryostat with continuous flow of $\mathrm{N}_{2}$ gas and excited by an Ar-ion laser line at $514.5 \mathrm{~nm}$ at a power density of $\sim 5 \mathrm{~mW} \mathrm{~mm}^{-2}$. PL measurements at $80 \mathrm{~K}$ were performed across the 1.0-1.7 $\mu \mathrm{m}$ spectral region using a sensitive, liquid-nitrogen-cooled P-I-N Germanium detector. Details of the samples are given in Table 1. Temperature dependence measurements on the SOI sample with the highest G-centre intensity was performed ranging from 80 to $110 \mathrm{~K} .80 \mathrm{~K}$ was adopted as the lowest measurement temperature as below this carrier freeze-out starts to occur in silicon.

In order to investigate the effect of annealing temperature, both SOI and bulk silicon wafers implanted with $4 \times 10^{18} \mathrm{~cm}^{-3}$ of carbon and $1 \times 10^{14} \mathrm{~cm}^{-2}$ of proton were prepared into 22 samples each to be annealed for $5 \mathrm{~min}$ at temperature ranges from $125^{\circ} \mathrm{C}$ to $375^{\circ} \mathrm{C}$. Samples without annealing from previous measurement were use as reference samples.

\section{RESULTS AND DISCUSSION}

Figure 1 shows the photoluminescence (PL) spectra, measured at $80 \mathrm{~K}$, of proton irradiated but not annealed bulk silicon and SOI samples. For reference, the PL spectra

TABLE 1. Sample details. The first carbon implant $\left(\mathrm{CI}_{1}\right)$ was at $30 \mathrm{keV}$ and the second implant $\left(\mathrm{CI}_{2}\right)$ at $10 \mathrm{keV}$. All samples were annealed at $1000^{\circ} \mathrm{C}$ for $20 \mathrm{~s}$ after the $\mathrm{C}$ implants. The average carbon volume concentrations were calculated using SUSPRE. Proton irradiation was performed at $2 \mathrm{MeV}$ after the $\mathrm{C}$ post-implant anneal. No further sample processing was done after the proton irradiation. The samples are labeled according to the processing conditions: B for bulk silicon and $\mathrm{S}$ for SOI substrates

\begin{tabular}{ccccc}
\hline Sample & $\begin{array}{c}\mathrm{CI}_{1} \text { dose } \\
\left(\mathrm{cm}^{-2}\right)\end{array}$ & $\begin{array}{c}\mathrm{CI}_{2} \text { dose } \\
\left(\mathrm{cm}^{-2}\right)\end{array}$ & $\begin{array}{c}\text { C volume concentration } \\
\left(\mathrm{cm}^{-3}\right)\end{array}$ & $\begin{array}{c}\text { Proton dose } \\
\left(\mathrm{cm}^{-2}\right)\end{array}$ \\
\hline B1, S1 & $4 \times 10^{13}$ & $1.1 \times 10^{13}$ & $4 \times 10^{18}$ & $\ldots$ \\
B2, S2 & $4 \times 10^{13}$ & $1.1 \times 10^{13}$ & $4 \times 10^{18}$ & $3 \times 10^{13}$ \\
B3, S3 & $4 \times 10^{13}$ & $1.1 \times 10^{13}$ & $4 \times 10^{18}$ & $1 \times 10^{14}$ \\
\hline
\end{tabular}


of samples without proton irradiation are also shown. A typical G-centre spectrum consisting of the narrow zero phonon line at $1.28 \mathrm{~mm}$ and the broader structured luminescence from 1.3 to $1.4 \mu \mathrm{m}$ resulting from several local phonon replica modes is observed in all the proton irradiated samples. In addition, in the proton irradiated bulk Si samples another zero phonon line luminescence feature is observed at $\sim 1.57 \mu \mathrm{m}$ due to the carbonoxygen $\left(\mathrm{C}_{\mathrm{i}} \mathrm{O}_{\mathrm{i}}\right) \mathrm{C}$-centre complex that occurs due to the high oxygen concentration in standard Czochralski (CZ) silicon. Both proton irradiation at $3 \times 10^{13}$ and $1 \times 10^{14}$ $\mathrm{cm}^{-2}$ gives similar G-centre peak intensities for the bulk silicon; this saturation indicates that sufficient interstitials have already been generated at the lower proton dose. For the SOI samples the irradiation at $1 \times 10^{14} \mathrm{~cm}^{-2}$ gives a significant enhancement over the irradiation at $3 \times 10^{13}$ $\mathrm{cm}^{-2}$. This difference indicates that the oxide interface in the SOI system may have some role in either sinking or blocking some of the generated interstitials. The G-centre peak intensity, although high in the SOI samples, appears lower than in bulk silicon samples implanted at the same conditions. The apparent reduction is likely to be the result of the oxide barrier preventing electron-hole pairs generated by the excitation laser deeper in the substrate reaching the carbon implanted region rather than reduced radiative recombination efficiency as, at the excitation wavelength used, only $20 \%$ of the light is absorbed in the silicon overlayer. Silicon phonon-assisted band-edge emission is observed in both the bulk silicon and SOI samples without the proton irradiation, and is higher in SOI than in bulk silicon. This is expected as SOI substrates used in this work have a higher quality of silicon overlayer which results in less non-radiative defects that reduce the luminescence efficiency (as indicated by the absence of the $\mathrm{C}_{i} \mathrm{O}_{i}$ oxygen related $\mathrm{C}$-centre emission in the implanted and irradiated SOI). No G-centre line emission is observed in either un-irradiated samples showing the importance of proton irradiation in forming the G-centre.

Temperature dependence measurements were carried out on the $1 \times 10^{14}$ proton irradiated SOI sample to investigate the temperature quenching of the G-centre emission. The results are shown in Figure 2. The G-centre peak intensity is highest at $80 \mathrm{~K}$ but decreases rapidly to almost a third of its original value at $90 \mathrm{~K}$. The peak intensity continues to quench and almost disappears by $110 \mathrm{~K}$. This behaviour is similar to that observed in bulk silicon samples (Berhanuddin et al. 2018). Whilst the SOI platform does not improve the usual quenching behavior it does not worsen it; as might have been possible due to any additional recombination at the oxide interface.

One concern about the G-centre is its known susceptibility to being annealed out after formation at relatively low process temperatures, meaning it could only be incorporated at the very back end of device processing. Figure 3 shows the G-centre peak intensity for both bulk silicon and SOI samples annealed over the range from 125 to $375^{\circ} \mathrm{C}$ after the $1 \times 1014$ proton irradiation. The SOI sample shows a large increase of $500 \%$ in the G-centre luminescence intensity on annealing at $125^{\circ} \mathrm{C}$ over the un-annealed SOI and is now $300 \%$ brighter than in the bulk silicon. The intensity decreases on further annealing at $150^{\circ} \mathrm{C}$ but is still $200 \%$ higher than the un-annealed sample and the bulk silicon where, in contrast, the G-centre peak intensity of the bulk silicon at $150^{\circ} \mathrm{C}$ has decreased by half compared to the same sample without annealing. Another increase in the intensity of the bulk silicon and the SOI samples occurs as the annealing temperature increases to $225^{\circ} \mathrm{C}$ and $250^{\circ} \mathrm{C}$, respectively. In both cases the G-centre intensity decreases rapidly above these temperatures before disappearing at $\sim 350^{\circ} \mathrm{C}$ in the SOI and $\sim 300^{\circ} \mathrm{C}$ in the bulk silicon. The different behaviour of the G-centre in SOI and bulk silicon is attributed to the formation and annealing

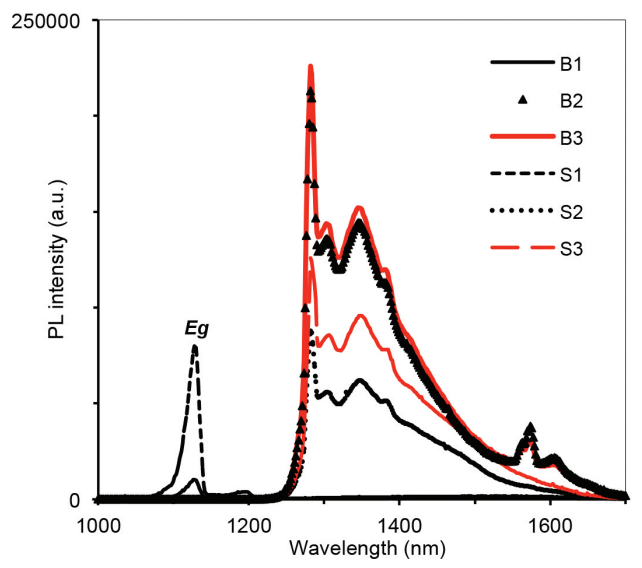

FIGURE 1. G-centre photoluminescence spectra in SOI and bulk silicon. PL spectra, measured at $80 \mathrm{~K}$, of bulk silicon and SOI samples implanted to $4 \times 10^{18} \mathrm{C} \mathrm{cm}^{-3}$ and annealed at $1000^{\circ} \mathrm{C}$ for $20 \mathrm{~s}$, followed by proton irradiation at $3 \times 10^{13} \mathrm{~cm}^{-2}(\mathrm{~B} 2, \mathrm{~S} 2)$ and $1 \times 10^{14} \mathrm{~cm}^{-2}(\mathrm{~B} 3, \mathrm{~S} 3)$. The spectra of samples without the proton irradiation $(\mathrm{B} 1, \mathrm{~S} 1)$ are also shown. For the proton irradiated samples the spectra are dominated

by the sharp G-centre emission centred at $1.28 \mu \mathrm{m}$ and the related local phonon replicas. Samples without proton irradiation show only the silicon band-edge emission at $\sim 1.1 \mu \mathrm{m}$. The oxygen related C-centre $(1.57 \mu \mathrm{m})$ is only observed in the irradiated bulk silicon samples 


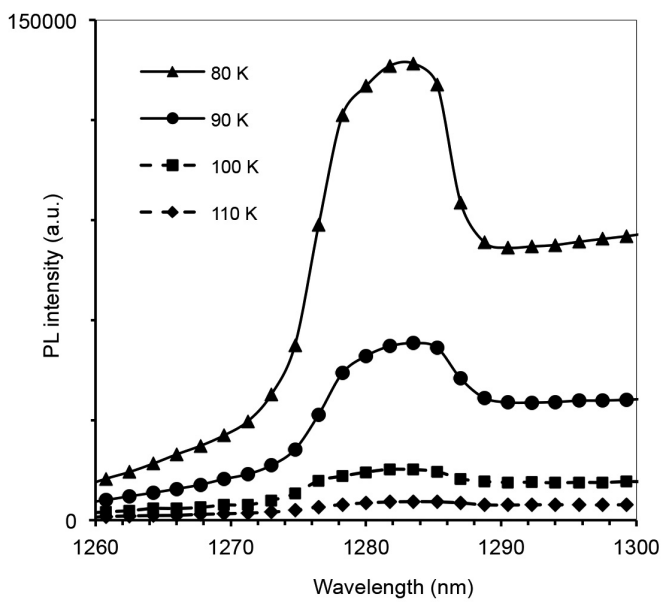

FIGURE 2. Photoluminescence spectra of SOI sample $\mathrm{S} 3\left(4 \times 10^{18} \mathrm{C} \mathrm{cm}-3\right.$ irradiated with $\left.1 \times 10^{14} \mathrm{H}^{+} \mathrm{cm}^{-2}\right)$ which were measured at temperature ranges from 80 to $110 \mathrm{~K}$. The G-centre peak luminescence quenches rapidly with increasing temperature. The G-centre luminescence shows similar behaviour both in SOI and bulk silicon samples previously reported

out of other competing recombination centres. Overall, the results showed that the optically active G-centre is significantly more intense in SOI rather than in bulk silicon over a wider process window. Both the different annealing behavior of the two systems and the complex temperature dependence of the annealing process suggest that the annealing out of the G-centre at rather low temperatures may be more controllable than previously presumed.

The bombardment of proton onto the silicon lattice has also created, in addition to the $\mathrm{G}$ - and C-centres, another known radiative centre, the $\mathrm{W}$-centre, which give luminescence at $1.22 \mu \mathrm{m}$. The presence of the W-line, attributed to silicon self-interstitial defect clusters formed after ion irradiation, indicates an excess of silicon interstitials created after the proton irradiation (Nakamura \& Nagai 2002). These silicon interstitials will compete with the main G-centre complex to scavenge either interstitial carbon or silicon.
Figure 4(a) shows the comparison between three optically active centres, the G, C and $\mathrm{W}$ centres in SOI samples. The carbon-oxygen $\mathrm{C}$-centre which has the luminescence peak at $1570 \mathrm{~nm}$ only starts to appear when the sample is annealed at $>275^{\circ} \mathrm{C}$ before disappearing again at $375^{\circ} \mathrm{C}$. However, the existence of the C-centre is relatively insignificant compared to the high intensity of the G-centre peak at the same annealing temperature. The results proved that there is a little or no competition between the $\mathrm{G}$ and the $\mathrm{C}$-centre in SOI platform. The W-centre intensity peak at $1220 \mathrm{~nm}$, attributed to only silicon interstitials, starts to appear in the SOI sample when annealed at $175^{\circ} \mathrm{C}$ and above. The W-centre's luminescence peak is steadily appearing in the SOI sample even when the G-centre's peak has disappeared and no longer observable. This is because the silicon interstitials are activated and more likely to aggregate with each other than with substitutional carbon at higher annealing temperature. By

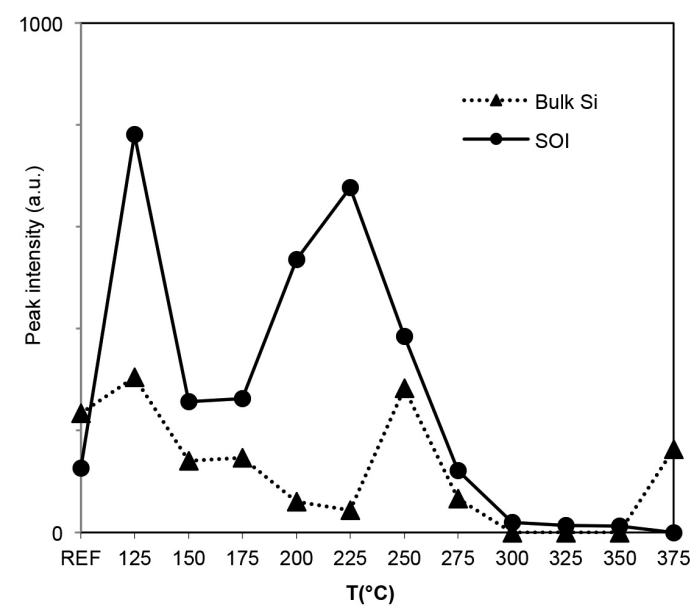

FIGURE 3. The G-centre's peak intensity for both bulk silicon (B3) and SOI (S3) samples at different annealing temperatures ranges from 125 to $375^{\circ} \mathrm{C}$. Generally, the G-centre's luminescence intensity in SOI sample are significantly higher than in bulk silicon after annealing 

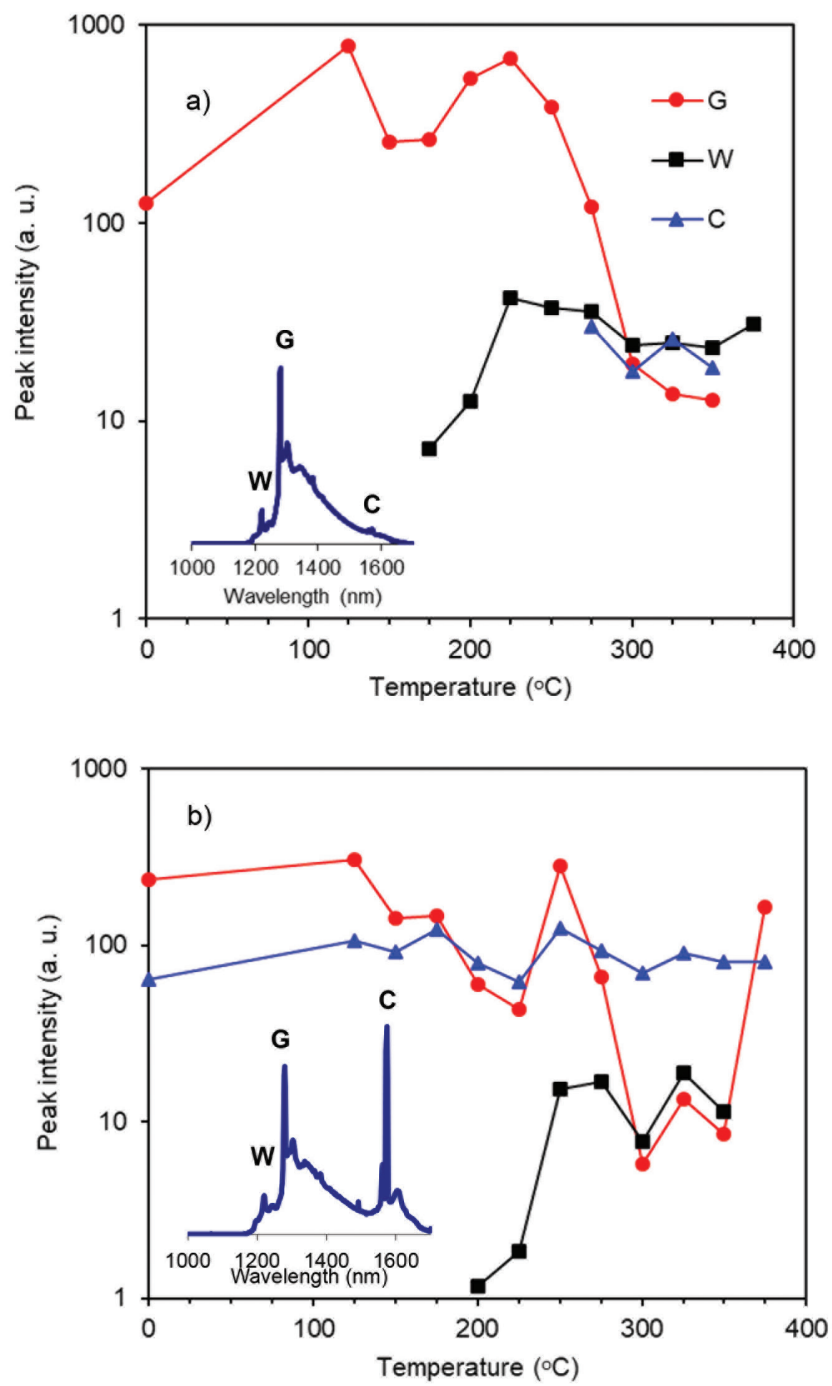

FIGURE 4. G-, C- and W-centres PL intensity versus proton irradiation post-anneal temperature. PL intensity, measured at $80 \mathrm{~K}$, for (a) SOI sample S3 and (b) bulk silicon sample B3. The carbon-oxygen C-centre is missing in the SOI sample preventing competition with the G-centre. Inset for 4(a) and 4(b) shows the PL spectrum for SOI and bulk samples, respectively, at anneal temperature of $275^{\circ} \mathrm{C}$. The main 3 point-defect centres, $\mathrm{G}, \mathrm{C}$ and $\mathrm{W}$ are also shown clearly in the spectrum

annealing the sample at higher temperature, the W-centre luminescence starts to dominate the spectrum.

Figure 4(b) shows the similar comparison of the G, C and W-centre peak luminescence but on the bulk silicon samples. Unlike SOI sample, the C-centre in bulk silicon sample is steadily present in the samples even at the highest annealing temperature. A competition between the $\mathrm{G}$ and $\mathrm{C}$-centre is also observed at $275^{\circ} \mathrm{C}$ where the peak intensity for both defect centres are similar. The C-centre starts to dominate when annealed at $275^{\circ} \mathrm{C}$ and above in which the $\mathrm{G}$-centre peak is no longer appear. Similar to SOI sample, the $\mathrm{W}$-centre peak is observed at $175^{\circ} \mathrm{C}$ and continue to increase gradually.

\section{CONCLUSION}

In summary, we have demonstrated and investigated, in a SOI platform, the formation of the radiative G-centre by serial implantation of carbon and high energy protons. This demonstration, that utilizes fully ULSI technology compatible processes, is an important next step if a G-centre based laser or gain structures are to be realized in silicon. A comparison of the G-centre behaviour in bulk silicon and SOI has been made. The luminescence in the SOI after a short low temperature, post proton irradiation, anneal is enhanced by $300 \%$ over the already high intensity luminescence observed in bulk silicon samples with a wider process window. However, as in bulk silicon, temperature quenching of the luminescence in SOI is observed and is therefore a real challenge that needs to be overcome to get room temperature operation. Nevertheless, quenching in similar silicon systems has been shown to be prevented or even reversed by further engineering of the material, again using ion implantation (Lourenco et al. 2005).

The complex post proton annealing behavior observed in bulk and SOI is attributed to competing non radiative 
centres that are themselves being formed and annealed out over the same temperature regime. The difference in this behavior between the two systems warrants further investigation and may offer some promise that the early annealing out of the G-centre might be controllable in the future.

\section{ACKNOWLEDGEMENTS}

We acknowledge the Royal Society UK for the award of the 2015 Brian Mercer Award for Innovation and the Universiti Kebangsaan Malaysia for the grant GGPM-2016-028.

\section{REFERENCES}

Bagiah, H., Halim, S.A., Chen, S.K., Lim, K.P. \& Awang Kechik, M.M. 2016. Effects of rare earth nanoparticles $\left(\mathrm{M}=\mathrm{Sm}_{2} \mathrm{O}_{3}, \mathrm{Ho}_{2} \mathrm{O}_{3}, \mathrm{Nd}_{2} \mathrm{O}_{3}\right.$ ) addition on the microstructure and superconducting transition of $\mathrm{Bi}_{1.6} \mathrm{~Pb}_{0.4} \mathrm{Sr}_{2} \mathrm{Ca}_{2} \mathrm{Cu}_{3} \mathrm{O}_{10+\delta}$ ceramics. Sains Malaysiana 45(4): 643-651.

Bao, J., Tabbal, M., Kim, T., Charnvanichborikarn, S., Williams, J.S., Aziz, M.J. \& Capasso, F. 2007. Point defect engineered Si sub-bandgap light-emitting diode. Optics Express 15(11): 6727-6733.

Beaufils, C., Redjem, W., Rousseau, E., Jacques, V., Kuznetsov, A.Y., Raynaud, C., Voisin, C., Benali, A., Herzig, T., Pezzagna, S., Meijer, J., Abbarchi, M. \& Cassabois, G. 2018. Optical properties of an ensemble of G-centers in silicon. Physical Review B 97(3): 035303.

Berhanuddin, D.D., Lourenço, M.A., Gwilliam, R.M. \& Homewood, K.P. 2018. The effect of temperature to the formation of optically active point-defect complex, the carbon g-centre in pre-amorphised and non-amorphised silicon. IOP Conference Series: Materials Science and Engineering 384(1): 012062.

Berhanuddin, D.D., Lourenço, M.A., Gwilliam, R.M. \& Homewood, K.P. 2016. Photoluminescence study of the optically active, G-centre on pre-amorphised silicon by utilizing ion implantation technique. IEEE International Conference on Semiconductor Electronics (ICSE2016). pp. 256-259.

Berhanuddin, D.D., Lourenço, M.A., Gwilliam, R.M. \& Homewood, K.P. 2012a. Co-implantation of carbon and protons: An integrated silicon device technology compatible method to generate the lasing G-Center. Advanced Functional Materials 22(13): 2709-2712.

Berhanuddin, D.D., Lourenço, M.A., Jeynes, C., Milosavljević, M., Gwilliam, R.M. \& Homewood, K.P. 2012b. Structural analysis of silicon co-implanted with carbon and high energy proton for the formation of the lasing G-centre. Journal of Applied Physics 112(10): 103110.

Boyraz, O.\& Jalali, B. 2004. Demonstration of a silicon raman laser. Optics Express 12(21): 5269.

Cloutier, S.G., Kossyrev, P.A. \& Xu, J. 2005. Optical gain and stimulated emission in periodic nanopatterned crystalline silicon. Nature Materials 4(12): 887-891.

Davies, G. 1989. The optical-properties of luminescence-centers in silicon. Physics Reports-Review Section of Physics Letters 176(3-4): 83-188.

Homewood, K.P. \& Lourenço, M.A. 2005. Light form silicon via dislocation loops. Materials Today 8(1): 34-39.
Jurbergs, D., Rogojina, E., Mangolini,L. \& Kortshagen, U. 2006 Silicon nanocrystals with ensemble quantum yields exceeding 60\%. Applied Physics Letters 88(23): 233116.

Kittler, M., Reiche, M., Arguirov, T., Seifert, W. \& Yu, X. 2005. Dislocation engineering for a silicon-based light emitter at $1.5 \mu \mathrm{m}$. IEEE International Electron Devices Meeting, IEDM Technical Digest. doi: 10.1109/IEDM.2005.1609533.

Lourenço, M.A., Milosavljević, M., Gorin,A.G., Gwilliam, R.M. \& Homewood, K.P. 2016. Super-enhancement of $1.54 \mu \mathrm{m}$ emission from erbium codoped with oxygen in silicon-oninsulator. Scientific Reports 5: 37501.

Lourenço, M.A., Milosavljević, M., Galata, S., Siddiqui, M.S.A., Shao, G., Gwilliam, R.M.\& Homewood, K.P. 2005. Siliconbased light emitting devices. Vacuum 78: 551-556.

Murata, K., Yasutake, Y., Nittoh, K., Fukatsu, S. \& Miki, K. 2011. High-density G-centers, light-emitting point defects in silicon crystal. AIP Advances 1(3): 032125.

Nakamura, M. \& Nagai, S. 2002. Influence of high-energy electron irradiation on the formation and annihilation of the photoluminescence W center and the center's origin in a proton-implanted silicon crystal. Physical Review B 66(15): 155204.

Ng, W.L., Lourenço, M.A., Gwilliam, R.M., Ledain, S., Shao, G. \& Homewood, K.P. 2001. An efficient room-temperature silicon-based light-emitting diode. Nature 410(6825): 192194.

Pavesi, L., Dal Negro, L., Mazzoleni, C., Franzò, G. \& Priolo, F. 2000. Optical gain in silicon nanocrystals. Nature 408(6811): 440-444.

Rong, H., Jones, R., Liu, A., Cohen, O., Hak, D., Fang, A. \& Paniccia, M. 2005. A continuous-wave Raman silicon laser. Nature 433(7027): 725-728.

Rotem, E., Shainline, J.M. \& Xu, J.M. 2007. Enhanced photoluminescence from nanopatterned carbon-rich silicon grown by solid-phase epitaxy. Applied Physics Letters 91(5): 051127.

Walters, R.J., Bourianoff, G.I. \& Atwater, H.A. 2005. Field-effect electroluminescence in silicon nanocrystals. Nature Materials 4(2): 143-146.

Webb, R. 2001 . Surrey University Sputter Profile Resolution from Energy deposition, SUSPRE. 2001: IBC, University of Surrey.

Yukhnevich,A.V.2007. Towards a silicon laser based on emissive structural defects. Solid-State Electronics 51(3): 489-492.

D.D. Berhanuddin*,N.E.A. Razak \& B.Y. Majlis

Institute of Microengineering and Nanoelectronics

Universiti Kebangsaan Malaysia

43600 UKM Bangi, Selangor Darul Ehsan

Malaysia

D.D. Berhanuddin*, M.A. Lourenço \& K.P. Homewood

Advanced Technology Institute

Faculty of Engineering and Physical Sciences

University of Surrey, Guildford

Surrey GU2 7XH

United Kingdom

M.A. Lourenço \& K.P. Homewood

Materials Research Institute and School of Physics and Astronomy 
Queen Mary University of London Mile End Road, E1 4NS London

United Kingdom

K.P. Homewood

School of Materials Science \& Engineering

Hubei University

Wuhan 430062

P.R. China
*Corresponding author; email: dduryha@ukm.edu.my

Received: 31 December 2018

Accepted: 26 February 2019 